\title{
SEJARAH PERKEMBANGAN MITOS SEBAGAI KEHIDUPAN SOSIAL MASYARAKAT SUGI KECAMATAN MORO KABUPATEN KARIMUN PADA TAHUN 1998-2015
}

\section{HISTORY OF MYTHS DEVELOPMENT AS SOCIAL LIFE OF SOCIAL COMMUNITY SUGI MORO KARIMUN DISTRICT \\ IN 1998-2015}

\author{
Desma Yulia $^{1}$, Afrinel Okwita ${ }^{2}$ \\ Program Studi Pendidikan Sejarah, Fakultas Keguruan dan Ilmu Pendidikan, \\ Universitas Riau Kepulauan \\ Desmayulia48@gmail.com
}

\begin{abstract}
Abstrak
Masyarakat Sugi masih mempercayai mitos dalam kehidupan sosial budayanya. Tujuan umum dalam penelitian ini adalah untuk mendeskripsikan sejarah perkembangan mitos sebagai kehidupan sosial masyarakat sugi pada tahun 1998-2015. Tujuan khusus penelitian ini adalah untuk menggambarkan bagaimana sejarah perkembanganmitosyang telah meresahkan masyarakat Sugi serta telah menelan korban jiwa. Jenis penelitian yaitu kualitatif, penelitian dibagi dalam dua tahap, yaitu penelitian kepustakaan dan penelitian lapangan. Penelitian kepustakaan berupa mencari buku-buku yang relevan dengan penelitian, kemudian penelitian lapangan berupa survey penetapan lokasi sampling, observasi serta melakukan wawancara mendalam (indepth interview). Metode yang digunakan dalam penelitian ini antara lain, metode deskriptif untuk menetukan teknik sampling. Mitos memberikan makna yang penting bagi pemikiran manusia .Cara menggunakannya dalam kehidupan yang nyata, dengan demikian pemikiran itu sendiri adalah sebagian dari mitos itu sendiri.Mitos selalu menunjukkan peristiwa masa lampau, pola-pola yang khas yang ada pada mitos merupakan hal yang membuat mitos menjadi relevan dan operasional dengan konteks yang sekarang.
\end{abstract}

Kata kunci: Sejarah, mitos, kehidupan social

\begin{abstract}
The Sugi society still believe in the myth of their cultural social life. The general purpose of this research is to describe the history of myth development as social life of society Sugi in 1998-2015. The specific purpose of this study is to describe how the history of mythical development that has been unsettling society Sugi and has claimed lives.The type of research is qualitative, the research is divided into two stages, namely library research and field research. Library research in the form of searching for books relevant to the research, later field research in the form of survey determination of sampling location, observation and in-depth interview (indepth interview). The method used in this research, among others, descriptive method to determine sampling technique. Myths give meaning that is important to the human mind. How to use it in real life, thus with thinking itself is part of the myth itself. Myth always shows past events, the distinctive patterns that exist in myths that make myths relevant and operational in the context of the present.
\end{abstract}

Keywords: history, myth, social life 


\section{PENDAHULUAN}

Indonesia merupakan negara yang memiliki keberagaman budaya dan adat istiadat. Identitas yang dimiliki indonesia salah satunya adalah kemajemukan. Kebudayaan menyangkut keseluruhan aspek kehidupan baik material dan non material. Suatu kebudayaan akan berkembang dari tahapan yang sederhana menuju tahapan yang lebih kompleks, merupakan bagian dari ciri khas suatu daerah yang menunjukan identitas daerah tersebut (Elly, 2006: 28).

Identitas dan kebudayaan sebuah daerah dapat dipengaruhi oleh masyarakat yang tinggal didaerah terdebut. Dengan cara mengacu kebudayaan sebagai abstraksi pengalamannya dimasa lampau, manusia mencoba untuk mengklasifikasikan fenomena yang ada dan menertibkan dalam alam pikirannya. Upaya pengklasifikasian tersebut tidak terlepas dari kebudayaan yang menguasai pola pikir dan sikap mental yang dimiliki. Seolah-olah manusia hanya melihat, mendengar dan memikirkan fenomena di sekitarnya berdasarkan pengalaman yang dimiliki, sehingga mitos merupakan cermin dari suatu kebudayaan pendukungnya.

Masyarakat dan lingkungan sebagai pendukung mitos berada dalam kehidupan sosial budaya. Mereka senantiasa berusaha untuk memahami diri dan kedudukannya dalam alam semesta, sebelum mereka menentukan sikap dan tindakan untuk mengembangkan kehidupannya dalam suatu masyarakat. Dengan seluruh kemampuan akalnya, manusia berusaha memahami setiap gejala yang tampak maupun yang tidak tampak. Dampaknya setiap masyarakat berusaha mengembangkan cara-cara yang bersifat komunikatif untuk menjelaskan berbagai perasaan yang mem punyai arti bagi kehidupannya (Iswidayati, 2007:181).

Manusia sebagai mahluk yang mampu menggunakan akal dan mempunyai derajat yang lebih tinggi daripada mahluk lainnya, namun ia tidak mampu menjelaskan semua fenomena yang ada disekitarnya. Untuk menguasai fenomena tersebut, diperlukan pemahaman terhadap kehidupan dengan cara mengembangkan simbol-simbol yang penuh makna. Simbol-simbol tersebut berfungsi untuk menjelaskan fenomena lingkungan yang mereka hadapi, terutama fenomena yang tidak tampak tetapi dapat dirasakan kehadirannya. Manusia dalam masyarakat dan lingkungan sebagai pendukung mitos berada dalam kehidupan sosial budaya. Mereka senantiasa berusaha untuk memahami diri dalam alam semesta, sebelum mereka menentukan sikap dan tindakan untuk mengembangkan 
kehidupannya dalam suatu masyarakat. Dengan seluruh kemampuan akalnya, manusia berusaha memahami setiap gejala yang tampak maupun yang tidak tampak.

Untuk dapat menguasai fenomena tersebut, diperlukan pemahaman terhadap kehidupan dengan cara mengembangkan simbol-simbol yang penuh makna. Simbol-simbol tersebut berfungsi untuk menjelaskan mitos-mitos yang ada dalam lingkungan sosial mereka. Kondisi sosial budaya dilingkungannya, terutama fenomena yang tidak tampak tetapi dapat dirasakan kehadirannya, seperti halnya yang terjadi dalam masyarakat Sugi.

Sugi adalah suatu wilayah yang ada di Kecamatan Moro Kabupaten Karimun. Berdasarkan grandtour yang penulis lakukan bahwasannya masyarakat ini masih mempercayai mitos dalam kehidupan sosial budayanya. Mitos seperti halnya manusia menjelaskan kegiatan yang tidak tampak namun cenderung pada kebudayaan sebagai perangkat simbol yang dapat memperjelas fenomena yang terjadi dalam lingkungan masyarakat. Lingkup penelitian ini mengkaji sejarah perkembangan mitos sebagai kehidupan sosial masyarakat Sugi Kecamatan Moro Kabupaten Karimun pada tahun 1998-2015. Lokasi penelitian meliputi Desa Sugi Kecamatan Moro Kabupaten Karimun.Mitos sebagai objek penelitian.

Adapun yang menjadi rumusan masalah dalam penelitian adalah melihat Sejarah Perkembangan mitos sebagai kehidupan sosialmasyarakat Sugi.Umumnya mitos dipercayai masyarakat dalam kehidupan social yang disampaikan dari mulut ke mulut. Oleh karena itu penelitian ini mengkaji tentang Sejarah perkembangan mitos sebagai kehidupan sosial masyarakat Sugi Kecamatan Moro Kabupaten Karimun Pada Tahun 1998-2015. Maka, dapat diajukan pertanyaan penelitian adalah bagaimana sejarah perkembanganmitos sebagai kehidupan sosialmasyarakat Sugi Kecamatan Moro Kabupaten Karimun pada tahun 19982015?. Berdasarkan latar belakang masalah di atas, adapun tujuan dalam penelitian ini adalah untuk mendeskripsikan sejarah perkembangan mitos sebagai kehidupan sosial masyarakat Sugi Kecamatan Moro Kabupaten Karimun pada tahun 1998-2015.

\section{Manfaat Penelitian}

Dari yang telah dipaparkan di atas maka peneliti dapat mengambil manfaat dari penelitian adalah sebagai berikut: Secara akademis penelitian ini diharapkan dapat menghasilkan karya tulis tentang Sejarah Perkembangan mitos sebagai kehidupan sosial masyarakat Sugi Kecamatan Moro Kabupaten Karimun Pada Tahun 1998-2015 dan secara praktis dapat memberikan gambaran dan dokumentasi secara tertulis tentang sejarah 
Desma Yulia Dan Afrinel Okwita; Sejarah Perkembangan Mitos Sebagai Kehidupan...

perkembanganmitos sebagai kehidupan sosial pada masyarakat Sugi Kecamatan Moro Kabupaten Karimun tahun 1998-2015.

\section{METODOLOGI}

Berdasarkan maksud dan tujuannya, penelitian ini digolongkan sebagai penelitian kualitatif deskriptif dengan pendekatan sosiologi dan antropologi. Penelitian ini dilakukan di Desa Sugi Kecamatan Moro Kabupaten Karimun Kepulauan Riau. Adapun alasan pemilihan lokasi ini karena sejarah perkembangan mitos sebagai kehidupan sosial masyarakat Sugi tahun 1998-2015. Masih ada dalam keseharian masyarakat sampai sekarang dan diceritakan setiap hari.Sehingga peneliti sangat tertarik melakukan penelitian di lokasi ini.Mitos merupakan cerita rakyat yang diceritakan secara turun-temurun yang dipercayai kebenarannya. Berdasarkan permasalahan, maka penelitian ini dapat dikategorikan ke dalam penelitian kualitatif yaitu penelitian yang menghasilkan data deskriptif berupa kata-kata tertulis atau lisan dari prilaku yang diamati.Jenis penelitian ini adalah studi kasus dengan studi kasus instrinsik yang dilakukan untuk memahami suatu kasus.

Dalam penelitian ini, pemilihan informan dilakukan teknik Purposive Sampling (sampel tujuan), yaitu penarikan sampel secara sengaja yang bertujuan untuk mengumpulkan informasi penelitian sesuai dengan tujuan penelitian. Dalam penelitian ini peneliti melakukan pengamatan terhadap aktivitas masyarakat Desa Sugi yang mengetahui tentang mitos.Dalam penelitian ini peneliti melakukan observasi, peneliti mengamati secara mendalam tetapi tidak diketahui oleh subjek penelitian.

Melalui observasi yang dilakukan sebelumnya, dimaksudkan agar mempermudah peneliti dalam melakukan wawancara dengan menggunakan bahasa Minang, karena informan mudah memahaminya.Waktu wawancara dengan informan dan memberikan pertanyaanpertanyaan yang tidak menyinggung informan.

Wawancara mendalam untuk mengumpulkan data dalam penelitian ini, dilakukan dengan mengajukan pertanyaan berdasarkan pedoman wawancara yang dibuat sebelum ke lapangan.Pertanyaan tersebut terus dikembangkan lebih lanjut dalam mengungkap data dari informan hingga didapat data yang lebih rinci.Waktu wawancara peneliti bebas menanyakan dan yang memberikan informasi menjawab pertanyaan yang peneliti berikan, walaupun demikian tidak lepas dari garis-garis besar permasalahan yang ditanyakan yang sesuai dengan pedoman wawancara (Endaswara, 2006). Dalam memperoleh keabsahan data peneliti melakukan triangulasi data, dengan menggunakan informan untuk mengumpulkan data yang 
sama. Cara yang dilakukan adalah dengan memberikan serangkaian pertanyaan yang dikembangkan dari pedoman wawancara terhadap informan, kemudian dicek ulang kepada informan yang berbeda. Triangulasi yang dilakukan dalam penelitian ini, selain yang telah dijelaskan di atas adalah dengan cara membandingkan data hasil pengamatan dengan wawancara, kemudian dibaca ulang data secara sistematik dan memeriksa data berulang kali, sehingga data tersebut dapat dipercaya dan dianggap valid kemudian dijadikan landasan untuk melakukan analisis. Analisis data dilakukansejak awal penelitian dilaksanakan, dilakukan secara berulang dan terus menerus sepanjang proses penelitian berlangsung. Untuk itu, dalam mengumpulkan data selalu dilengkapi dengan pembuatan catatan lapangan.Catatan lapangan bertujuan untuk mencatat hasil observasi dan wawancara. Analisis yang dilakukan dalam penelitian ini yaitu dengan langkah-langkah sebagai berikut (Miles dan Huberman, 1992):

\section{Reduksi data}

Reduksi data sebagai proses pemilihan, pemusatan perhatian pada penyederhanaan data yang muncul dari catatan lapangan. Reduksi data terjadi secara terus menerus selama prosesnya penelitian berlangsung.Setiap mengumpulkan data, data ditulis dengan rapi, terinci dan sistematis. Kemudian dibaca, dipelajari, dan dipahami agar data-data yang didapat bisa dimengerti. Selanjutnya dilakukan proses pemilihan yaitu memilih hal-hal yang penting sehingga sesuai dengan rumusan masalah.

\section{Penyajian data}

Penyajian data ini, peneliti berusaha untuk menyimpulkan kembali data-data yang telah disimpulkan pada tahap reduksi data sebelumnya dan pengambilan tindakan, dalam hal ini penyajian data yang ditampilkan melalui observasi dan wawancara dikelompokkan berdasarkan subjek penelitian untuk diambil kesimpulan.

Data yang telah disimpulkan diperiksa kembali dan dibuat dalam bentuk laporan penelitian.Jadi dengan adanya penyajian data, maka peneliti dapat memahami bagaimana mitos-mitos yang berkembang dalam masyarakat mulai tahun 1998-2015

\section{Penarikan Kesimpulan}

Penarikan kesimpulan yaitu dimulai dari permulaan data menganalisis, mencari kebutuhan pola-pola penjelasan dan proporsi, penarikan kesimpulan yang dilakukan setelah proses pengumpulan data dengan menggunakan bahasa yang ilmiah. Selanjutnya menganalisis data dengan cara membandingkan jawaban dari informan mengenai permasalahan penelitian yang sifatnya penting, dan jika dirasa sudah sempurna maka hasil 
penelitian yang telah diperoleh nantinya akan ditulis dalam bentuk laporan akhir. Kesimpulan akhir diambil dengan cara menggabungkan dan menganalisis keseluruhan data yang didapatkan di lapangan baik dengan wawancara maupun observasi yang dilakukan dalam penelitian ini tentang mitos-mitos mengenai santau.

\section{PEMBAHASAN}

Berdasarkan teori strukturalisme mitos bukan lagi hanya dongeng pengantar tidur, tetapi merupakan kisah yang memuat sejumlah pesan.Pesan-pesan ini tidak tersimpan dalam sebuah mitos yang tunggal, melainkan dalam keseluruhan mitos. Walaupun ada pesan, si pengirim pesan di sini tidak jelas, yang jelas hanyalah penerimaannya.Di sini diasumsikan bahwa si pengirim pesan adalah orang-orang dari generasi terdahulu, para nenek moyang dan penerimanya adalah generasi sekarang.Jadi di situ ada komunikasi antar dua generasi tetapi bersifat satu arah. Menurut Levi-Stratrss struktur mitos yang tercakup dalam model-model strukturalnya dan strktur mitos dalam konsep-konsep pemikiran manusia adalah sebuah satuan yang satu.Hal ini dikarenakan struktur mitos dilihatnya sebagai proses-proses dan pengkatagorian secara linguistic yang universal dan dengan demikian secara analogi kegiatan konseptual manusia bersifat universal.Mitos memberikan makna yang penting bagi pemikiran manusia yang bersangkutan dengan mitos itu sendiri.Cara menggunakannya dalam kehidupan yang nyata, dengan demikian pemikiran itu sendiri adalah sebagian dari mitos itu sendiri.Mitos selalu menunjukkan peristiwa-peristiwa masa lampau, pola-pola yang khas yang ada pada mitos merupakan hal yang membuat mitos menjadi relevan dan operasional dengan konteks yang sekarang.

\section{Mitos tentang Kemponan}

Kemponan adalah akibat yang diterima bagi mereka yang menolak makanan yang ditawarkan oleh orang lain.Akibat itu bisa bermacam-macam misalkan seperti kecelakan motor, terjatuh atau beberapa masalah lain dalam hidupnya yang efeknya langsung terasa ketika kita menolak makanan yang ditawarkan, bisa juga ketika saat perjalanan pulang kerumah dari tempat orang yang menawarkan kue atau makanan yang kita tolak lalu mengalami kecelakaan.

Kemponan sudah lama ada dalam keseharian masyarakat di daerah Sugi kecamatan Moro Kabupaten Karimun.Munculnya kemponan tersebut sudah semenjak nenek moyang dahulunya.Namun kapan tahun pastinya itu tidak diketahui. Berdasarkan hasil wawancara 
dengan masyarakat Sugi yang bernama Narindra Eka, yang sekarang berusia 35 tahun, dia menceritakan pengalamannya ketika pertama datang ke daerah Sugi Kecamatan Moro "ketika itu saya baru di angkat menjadi seorang guru di daerah Sugi, Kecamatan Moro. Ketika saya berkunjung kerumah warga di Sugi, saya disuguhi kue-kue legit dan minuman untuk di cicipi, namun saya menolaknya, waktu dalam perjalanan pulang saya mengalami kecelakan motor dan orang-orang menyebutnya kemponan karena saya tidak mencicipi sedikit makanan maupun minuman yang ditawarkan oleh warga yang saya kunjnungi itu. Seharusnya makanan yang ditawarkan oleh warga itu saya cicipi"

Sama halnya dengan Ibu Minik, wanita karir yang berprofesi sebagai Pegawai Negeri ini menceritakan soal Kemponan:

"Kemponan itu Kepercayaan masyarakat Melayu pada umumnya, setidaknya kita pegang sedikit saja makanan yang ditawarkan oleh kawan."

Ibu Minik menceritakan tentang Kawannya, orang Kubu Kabupaten Kubu Raya, saat menolak makanan yang ditawarkan, alhasil seperti halnya cerita Narindra Eka, Kawan Ibu Minik mengalami kecelakaan saat perjalanan pulang kerumah.Pengalaman yang senada juga diceritakan oleh YY (nama disamarkan) yang tinggal di daerah Sugi:

siang kemarin, ada teman asal Kapuas Hulu bersama istri dan anaknya datang ke rumah. Kami ngobrol dalam suasana lebaran yang agak terlambat.Ketika menjelang waktu makan, kami --saya dan emak, menyilakan mereka ikut makan.Mula-mula mereka menolak. "Udah.Masih kenyang."

Tetapi saya memaksa."Makanlah, biar sedikit.Ini, lauknya istimewa."

Akhirnya dia menyerah.Mau juga dia ikut gabung menghadap hidangan yang sudah diletakkan di ruang belampar di dapur.Sedangkan istrinya, mengurus anak lebih dahulu.Anaknya dibaringkan di ruang tengah.Saya dan teman mulai makan.Tak lama kemudian, istrinya juga bergabung.Dia ikut duduk mengelilingi hidangan.Lalu, istri teman itu kemudian menyentuh sisi mangkok satu persatu dengan telunjuk, serta menjumput sedikit nasi. Semula saya kira dia memilih mana makanan yang akan disendoknya lebih dahulu. Mungkin dia agak ragu mana jenis makanan yang akan diambil, pikir saya.Tetapi, ketika dia menyentuh, sepertinya dia menarik mangkok, dan kemudian mendorongnya sedikit, saya terperangah. Dugaan saya salah.Ternyata dia hanya menyentuh sisi mangkok.Setelah itu dia bangun dari duduk, dan menuju ruang tengah, tempat anaknya dibaringkan tadi. Dia jongkok di depan anaknya. Dengan telunjuk dia menyentuh kaki, tangan dan kening anaknya.Saya memandang 'prosesi' itu dari tempat saya duduk. Suaminya yang duduk di depan saya dan 
membelakangi ruang tengah, rupanya tahu apa yang dilakukan istrinya. Dia juga melihat keheranan saya.

"Biasa... pakai melepus,"

Aha..saya tahu itu. Cara menyentuh itu disebut 'melopus' dalam budaya kami di Riam Panjang, dan dalam bahasa teman saya 'melepus'.Maksud dari melepus adalah agar orang yang tidak ikut makan itu tidak kemponan.Kemponan bisa berbentuk kecelakaan.Misalnya, jatuh dari motor, jatuh dari pohon, dipatok ular, dll.Pokoknya semua kemungkinan yang timbul karena tidak makan saat ditawarkan makan, disebut kemponan.Karena bentuknya abstrak, semua orang takut.Setahu saya tidak ada orang berani melanggarnya.Saya juga termasuk orang yang takut terhadap kemponan itu. Karena itu, ritual melopus pun juga sering dilakukan. Saya terbiasa menyentuh makanan sedikit, atau kalau bisa mencicipinya. Jika tidak sempat makan, pada saat ditawarkan, saya akan menggigit bagian belakang telapak tangan ala kadarnya, digigit sedikit saja sebagai syarat. Masyarakat kami akan merasa lega dan percaya tidak akan kena kemponan jika sudah melakukan itu menurut YY ( nama yang disamarkan ).

Begitupun hasil wawancara yang penulis lakukan dengan pak Udin (nama yang disamarkan). Menurut pak Udin "seiring perjalanan waktu, kepercayaan pada kemponan sudah tidak lagi kuat. Jika terjadi sesuatu, tidak pernah lagi dikaitkan dengan kemponan itu, Saya ingat dua bulan lalu, anak saya Fa, dipatok ular di teras rumah. Sama sekali waktu itu saya tidak mengingatkan Fa kemponan.Setelah Fa dipatok ular, kami (saya dan emak) langsung menolong Fa dengan memijit luka, dan mengolesnya dengan otak ular yang mematok.Baru kemudian setelah itu saya membawa Fa ke Bidan, dan lalu dirujuk ke RS Otorita Batam.Saya ingat, kalau dikaitkan dengan kemponan, obat sementara Fa mestilah barang yang membuatnya kemponan.Jika dia kemponan nasi, maka nasilah obatnya. Jika kemponan air susu, maka susulah obatnya.Sering kali juga ketika ditawarkan makan, saya menolak - karena masih kenyang, dan lain-lain. Setelah itu, saya berjalan, tanpa melopus. Apapun kejadian selanjutnya, sama sekali tidak pernah dikaitkan dengan tawaran itu.Saya merenungkan perubahan itu. Ada nilai yang hilang di sana. Beruntunglah sebenarnya jika masih ada orang yang dapat menyelamatkannya".Hal ini dapat dijelaskan bahwa pada zaman sekarang sudah ada sebagian masyarakat yang tidak mempercayai lagi tentang kemponan.

\section{Mitos tentang Bomoh}

Sebagian besar hingga 95,79\% dari luas propinsi Riau terdiri atas perairan. Selain itu kondisi alam yang dihuni oleh Masyarakat Melayu Riau yang secara administrasi berada di 
dalam wilayah Propinsi Riau ini tidak cocok untuk bercocok tanam.Maka kebudayaan Masyarakat Riau terutama Masyarakat Sugi tergolong dalam masyarakat Laut.Maka tak heran jika mereka memiliki kepercayaan terhadap hal-hal bersifat mitos yang berkaitan dengan laut.

Sopher (dalam Koentjaraningrat 1993) pernah menyatakan bahwa religi yang mengatur perilaku orang Laut mengandung konsep dasar animisme-shamanisme, tetapi tidak meliputi semua aspek kehidupan mereka.Keyakinan mengenai hal-hal yang bersifat gaib mempengaruhi perilaku menanggapi ruh-ruh, kekuatan-kekuatan gaib, hari baik dan naas, hantu-hantu, mambang dan peri, dan sekaligus mencerminkan kekhawatiran mereka terhadap berbagai ancaman dunia gaib yang dapat merugikan atau mencelakakan kehidupan mereka.

Oleh karenanya orang Laut masih percaya akan kekuatan gaib, yang antara lain bersumber pada benda-benda seperti buntat, batu akik, akar bahar, keris dan sebagainya, dan pada benda-benda yang bersumber pada manusia. Bomoh atau dukun dianggap memiliki kekuatan gaib, yang dapat digunakan untuk tujuan baik maupun buruk, mencelakakan lawan, atau menghalau serangan lawan, serta menyembuhkan penyakit yang berasal dari perbuatan manusia maupun karena tersampuk atau "kemasukan" atau diganggu ruh, hantu, dan sebagainya. Dengan kekuatan gaibnya, seorang bomoh dianggap mampu mengatasi gejalagejala alam yang merugikan manusia, seperti menenangkan ombak dan badai.

Keseluruhan bomoh terdiri dari mereka yang bersekolah rendah dan menengah dan menpunyai ilmu dibidang agama. Dari segi sosio-ekonomi mereka mempunyai kedudukan yang sama dengan kebanyakan penduduk kampung atau masyarakat tempat mereka tinggal. Kedudukan dan gelar tidak begitu penting bagi mereka. Penglibatan mereka dalam bidang perbomohan tidak menampakkan mereka mempunyai kedudukan yang jauh berbeda dengan kedudukan penduduk lain. Mereka juga bekerja sebagai petani di sawah, petani di kebun, peternak,mencari tumbahan obat-obatan untuk ramuan obat. Rata-rata mereka berusia lebih dari 40 tahun, mempunyai keluarga dan tanah pertanian.

Keseluruhan bomoh adalah orang-orang yang mempunyai kelakuan baik, ramah, dan mempunyai kelakuan yang baik, rendah hati dan tidak sombong.Mereka senantiasa bersedia menerima siapa saja yang meminta pertolongan kepada mereka.Hal yang paling penting dari segi amalan ialah latihan kebatinan yang mereka ikuti. Untuk mendapatkan ilmu mereka berusaha mencari guru-guru agama yang terkenal meskipun terpaksa merantau ke daerah atau negeri lain. Mereka menghabiskan masa muda belajar secara bersungguh-sungguh untuk mendapatkan ilmu-ilmu agama yang diperlukan. 
Bomoh memberikan ayat-ayat Al-Quran yang menyatakan tentang sebab-sebab manusia dijadikan.Manusia diciptakan untuk menjadi khalifah atau pemimpin.Sebagai pemimpin setiap orang mempunyai peranan yang utama dan penting.Dia memimpin diri, keluarga, masyarakat dan seluruh umat manusia.Untuk manusia menjalankan tugasnya, maka Allah mengaruniakannya dengan akal.Dengan akal manusia bmempelajari semua ilmu.Ilmu mengenai penyakit dan perubatan adalah ilmu yang perlu dipelajari oleh manusia. Karena itu, para bomohmenterjemahkan bahwa ilmu yang mereka miliki adalah kepunyaan Allah, dan oleh karena itu ia perlu bermanfaat bagi manusia lainnya dan menjalankan tanggungjawab dengan sebaik-baiknya. Tanggungjawab untuk menolong sesame manusia tidak akan berhenti sampai manusia meninggal dunia.

Pengetahuan bomoh yang ada di Sugi tentang alam ghaib sangat luas dan tidak terbatas kepada makhluk ghaib semata-mata.Diantara yang diketahui ialah tentang perasaan dalaman seseorang, misalnya perasaan dengki dan cemburu. Ini diketahui melalui ilmu kebatinan yang membolehkan bomoh mengenal semua masalah cara mengobatinya. Dalam hal ini ilmu dan kemahiran bomoh mengenai hal-hal yang tersembunyi daripada penglihatan mata kasar manusia merupakan factor utama yang menjadi perobatan di sugi begitu unggul.Berdasarkan hal ini.Bisa disimpulkan bahwa perobatan Sugi adalah suatu paradigm yang mencakupi elemen-elemen yang tidak terdapat dalam paradigma bioperobatan.Bomoh yang khusus dalam melaksanakan shalat hajat dan dapat memerintahkan para malaikat menangani angkara syaitan harus diiktiraf sebagai pakar bidang spiritual. Berdasarkan hasil wawancara dengan ibuk naraya di daerah Sugi mengatakan bahwa:

"ketika dia sakit ataupun anggota keluarganya yang sakit ia lebih percaya berobat kepada bomoh atau dukun daripada bidan, karena melalui bomoh ia dapat sembuh darei penyakitnya dan tidak dengan biaya yang mahal bahkan obat yang harus dimakanpun ada disekitar tempat tinggalnya"

\section{Mitos tentang santau}

Sejalan dengan pernyataan Levi-Strauss di atas mitos santau ini merupakan cerminan dari pemikiran masyarakat Sugi, dimana pemikiran dan pengetahuan masyarakat mengenai santau terus diceritakan dalam keseharian mereka.Jadi mitos santau ini kedudukannya berada dalam pengetahuan masyarakat yang dibicarakan atau diceritakan kepada warga masyarakatnya.Struktur mitos berada dalam pikiran atau pengetahuan yang bersifat binary opposition, maksudnya pemikiran manusia yang mendasar bersifat kontradiktif.Masyarakat yang bersifat binary opposition yaitu bahwa warga masyarakat Sugi menganggap 
menggunakan Santau merupakan tindakan yang tidak baik dan merupakan suatu tindakan yang sangat bertentangan dengan Agama Islam yang mereka anut. Penggunaan santau yaitu mengirimkan penyakit pada orang lain bahkan mengakibatkan meninggal dunia.

Sesuai dengan fungsi santau yaitu ramuan yang menyebabkan orang lain menderita sakit bahkan meninggal dunia. Hingga saat ini tetap bertahan digunakan oleh sebagian masyarakat Sugi.Penggunaan Santau ini diyakini terjadi di dalam keseharian masyarakat.Mitos-mitos yang diyakini sebagian besar dipengaruhi oleh beberapa factor, diantaranya; factor keturunan, factor pendidikan, dan factor keyakinan atau kepercayaan. Berikut ini dijelaskan lebih rinci mengenai mitos penggunaan santau masih ada sampai sekarang sebagai berikut:

Pertama, santau merupakan suatu ramuan sejenis tuba yang diwariskan turun temurun yang diberikan dari orang tuanya, sehingga santau harus diberikan terhadap orang lain dalam jangka waktu yang telah ditentukan supaya dia dan keluarganya sendiri tidak menjadi korban. Orang yang memiliki santau yaitu warisan dari keturunan nenek moyangnya dahulu, dan tidak pernah dibuang oleh pemilik.

Hal ini dijelaskan oleh informan NN (nama disamarkan):

"menurut sepengetahuan saya, orang-orang yang masih menggunakan santau itu sampai sekarang ini karena dia keturunan orang yang mempunyai santau sejak dahulunya, jadi santau masih ada di daerah Sugi ini, karena orang yang pemiliknya menurunkan pada anak didiknya"

Kedua, santau digunakan kerena dendam dengan cara memberikan penyakit terhadap orang yang mereka maksud. Pernyataan ini dijelaskan oleh informan AA, yang mengatakan bahwa;

“ada lagi sebagian masyarakat yang masih menggunakan santau sampai sekarang, dengan cara menyuruh orang yang memiliki santau untuk memberikan ramuan tersebut kepada orang yang dimaksud, dengan imbalan uang, emas, dan barang berharga lainnya”.

Ketiga, karena ke pemilikan seperti harta pusaka, lahan yang diperebutkan yang menyebabkan perselisihan antar dua kubu yang kalah menyebabkan kecemburuan social. Sebagian masyarakat mencari solusinya, sebagian lagi membalas dengan sesuatu yang tidak baik seperti mengirimkan penyakit terhadap orang lain.

Hal ini di ungkapam oleh informan yang bernama RD (nama disamarkan) yang mengatakan bahwa: 
"ketika terjadi perselisihan yang disebabkan oleh perebutan harta pusaka, seperti sawah, ladang, dan perumahan. Orang yang mempunyai santau akan langsung mengirimkan sesuatu seperti makanan dan sebagainya kepada musuhnya, sehingga mereka yang terkena santau akan menderita sakit yang berkepanjangan dan sangat susah dicarikan obatnya”.

Keempat, karena factor ekonomi, orang yang mempunyai ramuan tersebut juga memiliki kepandaian dalam mengobati orang yang terkena kiriman penyakit dari yang punya santau.Menggunakan santau juga sebagai mata pencarian bagi pemiliknya, orang yang memiliki tujuan tertentu ada juga yang meminta jasa mereka, misalnya saja balas dendam terhadap lawan. Orang tahu bahwa si A yang memiliki keahlian tersebut. Tidak hanya sebagian masyarakat Sugi saja yang meminta jasanya, malahan ada juga dari masyarakat luar sugi.

Hal senada dengan para informan di atas juga diungkapkan oleh DY:

“Orang yang mempunyai santau selain karena keturunan yang mengharuskan mereka untuk menggunakannya juga digunakan untuk mencari uang.Jadi adakalanya orang yang berobat atau meminta obat akan diminta bayaran sesuai dengan keinginan orang yang mempunyai santau itu sendiri”.

\section{KESIMPULAN DAN SARAN}

\section{Kesimpulan}

Berdasarkan hasil penelitian yang telah diperoleh dapat disimpulkan bahwa:

1. Masyarakat Sugi Kecamatan Moro Kabupaten Karimun sampai saat ini masih mempercayai tentang mitos-mitos yang berkembang dalam masyarakat Sugi,walaupun dengan perkembangan zaman yang semakin modern namun sebagian besar masyarakat Sugi masih mempercayai mitos dan hanya sebagian kecil yang sudah tidak percaya lagi dengan mitos yang berkembang dalam masyarakat Sugi yang sudah dipercayai semenjak nenek moyang zaman dahulunya. Mitos-mitos yang berkembang tersebut diantaranya: mitos tentang kemponan, mitos tentang bomob, mitos tentang santau.

2. Sejalan dengan pernyataan Levi-Strauss di atas mitos tentang Kemponan, mitos tentang Bomoh, mitos tentang Santau ini merupakan cerminan dari pemikiran masyarakat Sugi, dimana pemikiran dan pengetahuan masyarakat mengenai mitos terus diceritakan dalam keseharian mereka. Jadi mitos ini kedudukannya berada dalam pengetahuan masyarakat yang dibicarakan atau diceritakan kepada warga masyarakatnya. Struktur mitos berada dalam pikiran atau pengetahuan yang bersifat binary opposition, maksudnya pemikiran 
manusia yang mendasar bersifat kontradiktif. Masyarakat yang bersifat binary opposition yaitu bahwa warga masyarakat Sugi menganggap mempercayai kemponan, bomoh, Santau merupakan tindakan yang tidak baik dan merupakan suatu tindakan yang sangat bertentangan dengan Agama Islam yang mereka anut. Penggunaan santau yaitu mengirimkan penyakit pada orang lain bahkan mengakibatkan meninggal dunia.

\section{Saran}

Berdasarkan hasil penelitian yang telah diperoleh maka peneliti merekomendasikan hal-hal sebagai berikut:

1. Perlu dilakukan sosialisasi oleh pemerintah kota Batam tentang perkembangan ilmu pengetahuan dan tekologi kepada masyarakat Sugi Kecamatan Moro Kabupaten Karimun

2. Pihak terkait agar dapat memperhatikan perkembangan pendidikan bagi masyarakat Sugi.

\section{REFERENSI}

Ahimsa-Putra, Heddy Shri. 2001. Strukturalisme Levi-Strauss:Mitos dan Karya Sastra. Yokyakarta: Galang Press.

Badcock, Christopher R. 2008. Levis-Strauss Strukturalisme dan Teori Sosiologi.. Yogyakarta: Pustaka Pelajar

Danandjaya, James. 1991. Folkor Indonesia: Ilmu Gosip, Dongeng, dan lain-lain. Jakarta. Pustaka Utama Grafiti.

Koentjaraningrat. 1980. Sejarah Teori Antropologi. Jakarta: UI Press.

Navis.A.A, 1984.Alam Takambang Jadi Guru. Jakarta: Graffiti Pers.

Miles dan Huberman.1992.Analisis data Kualitatif. Jakarta: UI Pers

Saifuddin, Ahmad Fedyani. Antropologi Kontemporer. Jakarta: Kencana. 2005 